DOI: https://doi.org/10.24127/ajpm.v10i2.3447

\title{
BLENDED LEARNING IN TEACHING MATHEMATICS
}

\author{
Yullys Helsa ${ }^{1^{*}}$, Darhim ${ }^{2}$, Dadang Juandi ${ }^{3}$, Turmudi ${ }^{4}$ \\ ${ }^{1 *}$ Universitas Negeri Padang, Padang, Indonesia \\ ${ }^{2,3,4}$ Universitas Pendidikan Indonesia, Bandung, Indonesia \\ ${ }^{*}$ Corresponding author \\ E-mail: $\quad \frac{\text { yullys@fip.unp.ac.id }}{\text { darhim@upi.edu }^{2)}}$ \\ dadang.juandi@upi.edu ${ }^{3)}$ \\ turmudi@upi.edu ${ }^{4}$
}

Received 03 January 2021; Received in revised form 07 March 2021; Accepted 24 June 2021

\begin{abstract}
The background of this research was the development of blended learning in teaching mathematics. This study aimed to determine the benefits of blended learning in teaching mathematics by analyzing previous research. The method in this study is a systematic literature review (SLR), it descriptive based survey in the form of an analysis of 25 articles from the Science Direct database in the 2010-2020 period. The results showed that there are many benefits of blended learning in mathematic, which includes: to improve mathematical thinking skills, develop good perceptions, improve learning outcomes, increase self-regulation, increase thinking/problem-solving skills, improve communication skills, increase student participation, simplify the assessment process, increase computational thinking skills, and critical thinking skills. The most significant benefit of blended learning is student learning outcomes, shown in $52 \%$ of the articles. The research implies the importance of supporting teachers in identifying the objectives of blended learning.
\end{abstract}

Keywords: Blended learning; mathematics; systematic literature review (SLR).

\begin{abstract}
Abstrak
Penelitian ini dilatarbelakangi berkembangnya inovasi pembelajaran blended learning pada proses pembelajaran matematika sehingga perlu diketahui apa saja manfaat dari penerapan blended learning tersebut. Tujuan penelitian ini adalah untuk mengetahui kebermanfaatan blended learning dalam proses pembelajaran matematika dari penelitian yang telah dilaksanakan sebelumnya. Metode penelitian ini menggunakan systematic literature review (SLR), dengan menggunakan pendekatan deskriptif berbasis survei melalui analisis terhadap 25 artikel yang terdapat pada database science direct pada rentang waktu 2010-2020. Hasil penelitian menunjukan ada banyak manfaat blended learning dalam pembelajaran matematika yaitu meningkatkan kemampuan berpikir matematis, memberikan persepsi yang baik, meningkatkan hasil belajar, meningkatkan regulasi diri, meningkatkan kemampuan berpikir, meningkatkan kemampuan komunikasi, meningkatkan aktivitas siswa, mempermudah proses penilaian, meningkatkan kemampuan berpikir komputasi dan meningkatkan kemampuan berpikir kritis. Manfaat penerapan blended learning yang lebih besar terdapat pada proses peningkatkan hasil belajar dengan mendapatkan persentase 52\% dari jumlah artikel. Implikasi penelitian ini berguna untuk mempermudah guru dalam menentukan tujuan pelaksanaan penerapan blended learning.
\end{abstract}

Kata kunci: Blended learning, matematika; systematic literature review (SLR).

This is an open access article under the Creative Commons Attribution 4.0 International License

\section{INTRODUCTION}

The globalization era, in which there is a rapid development of information technology (Marcotullio 2001), is characterized by a worldwide trend in mastering the use of 
technology. This development is marked by the number of people who use smartphones for daily use. Smartphones do not only function as tools but also as a means to access the internet, which is a part of information technology.

The internet service management association states that there has been an increase in the use of the internet in Indonesia from 2017 to 2019 (Affan and Thohir 2020). It shows that Indonesians have used the internet in their daily life. The use of the internet among Indonesians is mainly through smartphones. The Indonesian Ministry of Information and Communication stated that Indonesia ranked as the fourth country that actively uses smartphones. A digital marketing research institute, Emaker, also mentions that in 2018, more than one hundred million Indonesian citizens are active smartphone users. It further proves that Indonesia is one of the countries that actively use smartphones in daily life.

The majority of active smartphone users in Indonesia are teenagers, specifically older elementary school students, junior high, and senior high school students. The use of smartphones among teenagers is for communication (through various social media platforms) and entertainment (i.e., mobile games). Meanwhile, the use of smartphones as a learning tool has not reached its full potential. Technology, in general, is functional in every field, including education, especially for learning. Smartphones as technological products are useful learning tools. Smartphones are useful for finding related learning resources through the information search feature (Buck, McInnis, and Randollph 2013; Tossell et al. 2015). Besides, smartphones are also used as a means of accessing LMS
(Learning Management System) (Kim \& Shon, 2011; Cho et al, 2018) as a part of the digital learning process. Therefore, smartphones support the use of technology in the learning process in this globalization era.

Furthermore, the 2013 curriculum mandated by the Ministry of Education in Indonesia also supports technologybased learning. The 2013 curriculum requires the use of technology in all subjects, including mathematics. Mathematics is a subject that students must master at all levels starting from the elementary level up to the tertiary level (Kenedi 2019). Mathematics is a subject that provides logical connections to all elements that will help students solve problems in their life. However, many students still dislike learning mathematics, which results in low learning outcomes of mathematics ( Latterall \& Wilson, 2016; Markovits \& Forgasz, 2017). Mathematics requires an abstract thinking process. Therefore, teachers must develop contextual learning activities that align the characteristics of mathematics with students' characteristics. With this approach, students will feel less overwhelmed during learning.

Students' tendency to use technology is the turning point of classroom innovations. The sheer number of students who have smartphones has since resulted in technology-based mathematics learning. One of the many innovations related to technology-based learning is the blended learning approach (Eliyasni, Kenedi, and Sayer 2019) Blended learning is a learning approach that combines face-to-face learning with online learning (Yustina, Syafii, and Vebrianto 2020). Online learning is developed through LMS as a learning 
process tool. Besides, blended learning is also widely researched. (Eliyasni et al. 2019) stated that blended learning improves students' HOTS (higher order of thinking skills) abilities. Setyaningrum (2018), mentioned that blended learning increases students' understanding of mathematical concepts. Similarly, Yaghmour (2016) confirmed that blended learning improves students' learning outcomes, while Lin et al (2016), stated that it increases student performance in the mathematics learning process. Moreover, Rifa'i (2018), stated that blended learning develops a positive perception of mathematics. Based on the various research, blended learning benefits students in understanding mathematics.

Some previous studies have investigated the implementation of blended learning in higher education context. Waha and Davis (2014), revealed that university students perceived blended learning environment as a learning approach that provides more flexibility and convenience in their learning. However, this surveybased study has given a limitation in exploring the students' perspective on blended learning. Meanwhile, another study by Alebaikan and Troudi (2010), has uncovered that the adaption of blended learning approach in traditional university culture in Saudi universities has been the main challenge. Instructor resistance and students' lack of discipline and responsiveness are the key challenges in traditional didactic classroom in most Saudi universities. Similarly, in the Indonesian context, teaching and learning practices in many Indonesian universities are lecturebased dominated, and the investigation on blended learning from university students and teachers' experience has a scant regard.

Based on the findings of the previous study, istated that not all teachers are familiar with the use of technology in the learning process,(Zainuddin and Keumala 2018). This indicates that many teachers do not know that technology in learning has a positive advantage over the learning process. It also indicates that many teachers do not know the benefits of blended learning. This is also in line with the findings that there are no previous studies that summarize the benefits of blended learning in teaching mathematics. Therefore, the purpose of this study is to determine the benefits of blended learning in teaching mathematics.

\section{METHOD}

The method in this research is systematic literature review (SLR), this study is in the form of a survey. The sample is research journals from the ScienceDirect database on the use of blended learning in teaching mathematics. The publication year ranges from 2010 to 2020 and the number of articles is 25 articles. The keywords for the articles are "blended learning" and "mathematics". The initial step of this research was to collect articles related to blended learning in mathematics. Then, the researchers classified the articles based on their title, year, journal name, the topic of study, context, research subjects, mathematical content, and mathematical abilities.

The purpose of this study was to determine the benefits of blended learning in mathematics. Thus, the researchers analyzed each predetermined article. 


\section{RESULT AND DISCUSSION}

This research was conducted by analyzing 25 journals related to blended learning in teaching mathematics. The first step was finding articles related to blended learning in mathematics. The keywords to find the articles were "blended learning" and "mathematics" and the query of said keywords results in 25 titles. These titles are found in 13 journals, namely procedia-social and behavioral sciences journals, nurse education in practice, nurse education today, computers in human behavior, the internet and higher education, journal of cleaner production, computers \& education, telematics and informatics, studies in educational evaluation, the internet and higher education, safety science, procedia cirp and the international journal of hydrogen energy.

After finding the title, the researchers classified the articles based on their publication year. Thus, the articles' classification by year is as Figure 1.

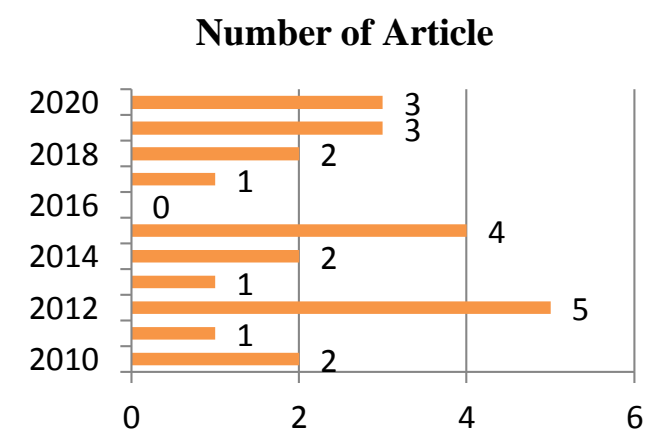

Figure 1. Classification by year

Figure 1 implies that the highest percentage of journals related to blended learning in mathematics is in 2012. Based on the researchers' analysis of the 2012 articles, it was found that various researchers revealed that blended learning in mathematics provides many benefits, such as improving mathematical thinking skills, improving learning outcomes, improving thinking/problem-solving skills, improving communication skills, and increasing learning participation. In fact, blended learning efficiently uses technology to improve learning quality (Dziuban et al. 2018).

The researchers also classified articles based on their research methodology. The results of this classification are shown in Figure 2.

\section{Research Methodology}

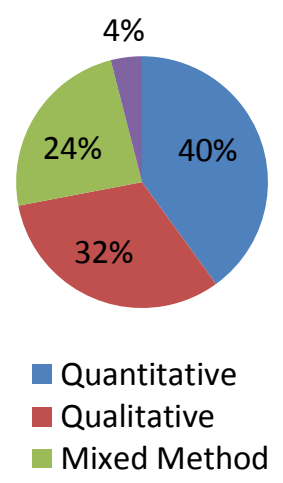

Figure 2. Classification Based on Research Methodology

Figure 2 shows that most of the research related to blended learning in mathematics is in the form of quantitative research. In other words, studies related to blended learning in mathematics are conducted to determine the relationships between variables, such as the relationship between blended learning and parts of mathematical processes. It is in line with Cresswell (2013) Crdefinition of quantitative research as scientific research systematically structured against a phenomenon and its parts as well as the relationship to one another.

Furthermore, the classification is also carried out based on the effectiveness of blended learning in teaching mathematics. The researchers 
DOI: https://doi.org/10.24127/ajpm.v10i2.3447

analyzed 25 journals to summarize the benefits of blended learning in teaching mathematics. The results of the analysis on Table 1.

Table 1. Results of the analysis of the benefits of blended learning on teaching mathematics

\begin{tabular}{|c|c|c|}
\hline No & Benefits & References \\
\hline 1 & $\begin{array}{l}\text { Improve mathematical thinking } \\
\text { skills }\end{array}$ & Kashefi, Ismail, and Yusof (2012) \\
\hline 2 & Develop good perceptions & $\begin{array}{l}\text { O'Reilly, R., Ramjan, L. M., Fatayer, M., } \\
\text { Stunden, A., \& Gregory, L. R. (2020); }\end{array}$ \\
\hline 3 & Improve learning outcomes & $\begin{array}{l}\text { (Asarta and Schmidt 2020; Berga et al. 2021; } \\
\text { Chen et al. 2009; Deschacht and Goeman } \\
\text { 2015; Gröschl et al. 2015; Kashefi et al. } \\
\text { 2012a; Morales-Menendez and Ramírez- } \\
\text { Mendoza 2019; Schlingensiepen 2014; Stuart } \\
\text { 2014; Wahyu, Putra, and Simatupang 2013; } \\
\text { Yao,C.2019; Zacharis 2015) }\end{array}$ \\
\hline 4 & $\operatorname{Imp}$ & $\begin{array}{l}\text { ( Rienties, B., Tempelaar, D., Nguyen, Q., \& } \\
\text { Littlejohn, A. 2019) }\end{array}$ \\
\hline 5 & $\begin{array}{l}\text { Support thinking/problem-solving } \\
\text { skills }\end{array}$ & fi et al. 2012a) \\
\hline 6 & Improve communic & $(\mathrm{Ka}$ \\
\hline 7 & Increase students' pa & $\begin{array}{l}\text { ( Baragash, R. S., \& Al-Samarraie, H. 2018; } \\
\text { Haron, H., Abbas, W. F., and Abd Rahman, N. } \\
\text { A. (2012); Vo, H. M., Zhu, C., and Diep, N. } \\
\text { A. 2017) }\end{array}$ \\
\hline 8 & Simplify the assessment process & $\begin{array}{l}\text { (Bauk, S. I. 2015; Yigit, T., Koyun, A., } \\
\text { Yuksel, A. S., \& Cankaya, I. A. 2014) }\end{array}$ \\
\hline 9 & $\begin{array}{l}\text { Improve computational thinking } \\
\text { skills }\end{array}$ & $\begin{array}{l}\text { ( X., Olabe, M. Á., Olabe, J. C., and Rico, M. } \\
\text { J. 2018; ) }\end{array}$ \\
\hline 10 & Improve critical thinking skills & Akyüz, H. İ., \& Samsa, S. (2009) \\
\hline
\end{tabular}

Table 1 shows the various benefits of implementing blended learning in teaching mathematics. Further emphasizes that blended learning benefits the teaching and learning of mathematics, namely through improving mathematical thinking skills, developing good perceptions, improving learning outcomes, increasing selfregulation, increasing thinking/problemsolving skills, improving communication skills, increasing students' participation, simplifying the assessment process, increasing computational thinking skills, and improving critical thinking skills.

Based on these arguments, the researchers conducted a qualitative analysis of the benefits of blended learning. The analysis aims to determine which benefits have the most significant influence on the mathematics learning process. The results are shown on figure 3.

Figure 3 shows that blended learning has a significant effect on mathematical learning outcomes. It further proves that blended learning can 
be improving students' mathematics learning outcomes. Blended learning is a learning process that combines online and face-to-face learning (Francis \& Shannon, 2013).

\section{Benefits of Blended Learning}

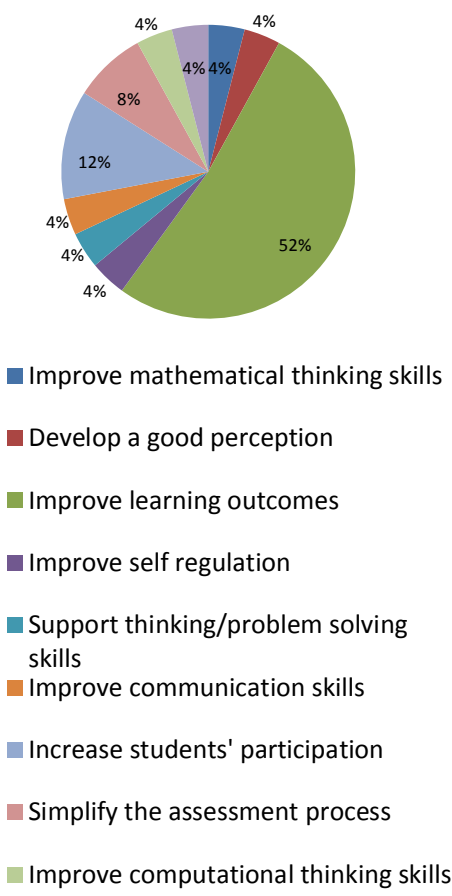

Figure 3. Percentage of the benefits of blended learning in mathematics

Based on the analysis, it is found that blended learning improves mathematics learning outcomes. Several factors support this notion. During blended learning, students can independently study classroom materials and access information online, as well as other related sources on the presented material. As a result, students are free to revisit the material. Besides, if students cannot comprehend the material during online learning, face-toface learning is presented in person with the teachers. Blended learning is presented both online and offline so that the learning process is efficient
(Lothridge et al, 2013),. Also, teachers provide learning materials online so students can access them regardless of time and place. Teachers can also evaluate through quizzes or assignments and post them online. It also affects the learning atmosphere. Blended learning transforms a rigid and systematic atmosphere into a fun learning experience which will lead to a meaningful process that improves learning outcomes. This result is in line with research that affirms blended learning as a learning innovation that creates a flexible technology-based learning process (Ayala 2009).

Additionally, blended learning improves learning outcomes since its characteristics align with the characteristics of learning in the globalization era. Globalization is marked by the development of technology on a large scale. This technological development results in a change of mindset and behavior towards technological patterns. This also means that in this era, students are more likely to prefer using technology. Therefore, students prefer blended learning, which in turn affects their learning outcomes. Blended learning is, therefore, technology-based learning that is suitable in this era (Sudirman and Palawi 2019).

In addition to improving learning outcomes, analysis result also shows that blended learning improves thinking skills, such as mathematical thinking skills, computational thinking skills, and critical thinking skills. Based on the results of this study, it shows that blended learning is not only restricted to a learning process that is divided into in-person and online learning. Even though learning is carried out online, teachers still provide mathematical problems that students must solve. With 
the combination of face-to-face and online learning, the problems given remain challenging to improve students' thinking skills. Therefore, blended learning directly impacts students' thinking skills (Dwiyogo, 2018).

Moreover, this analysis proves that blended learning can foster good perceptions of mathematics. Students have always perceived mathematics as an unpleasant and rigid subject. However, the implementation of blended learning was able to change these perceptions. This is because, during the learning process, blended learning is presented using technology, which is a tool that students prefer. Thus, blended learning as technologybased learning aligns with the characteristics of students of today (Attard and Holmes, 2020). Another analysis also states that blended learning improves students' selfregulation in learning mathematics. With the use of an online system in blended learning, students must learn to manage themselves. This is because, during online learning, students independently learn without the supervision of a teacher. Thus, blended learning improves the students' selfregulation as it trains students to independently manage their learning process, (Lynch and Dembo 2004, Francis and Shannon 2013).

Lastly, blended learning also increases students' participation and communication skills. Blended learning allows teachers to present mathematical problems that can be solved by combining students' technical skills and verbal skills. In other words, students are actively required to master technical skills to solve problems. Once the problem is solved, students must communicate the problem both written and orally. Thus, blended learning is a meaningful tool to improve learning performances and students' communication skills (Brodersen \& Melluzzo, 2017).

\section{CONCLUSION AND SUGGESTION}

In conclusion, there are many benefits of implementing blended learning in teaching mathematics, which includes improving mathematical thinking skills, develop good perceptions, improving learning outcomes, increasing self-regulation, improving thinking/problem-solving skills, increasing communication skills, increasing students' participation, simplifying the assessment process, increasing computational thinking and critical thinking skills. The most significant benefit of implementing blended learning is the improvement of learning outcomes shown in $52 \%$ of the articles.

Based on these findings, there are still many research variables related to blended learning that have not been researched to see the benefits. Therefore, it is advisable to conduct research from various aspects in the blended learning process in order to illustrated the benefits of blended learning thoroughly.

\section{REFERENCES}

Affan, M., \& Thohir, A. (2020). Studying Religion Through the Internet among Millennial Muslims: Causes and Consequences. FIKRAH, 8(1), 4352.

Akyüz, H. İ., \& Samsa, S. (2009). The effects of blended learning environment on the critical thinking skills of students. Procedia-Social and Behavioral Sciences, 1(1), 1744-1748. 
Alebaikan, R., \& Troudi, S. (2010). Blended learning in Saudi universities: challenges and perspectives. ALT-J, 18(1), 4959.

Asarta, C. J., \& Schmidt, J. R. (2020). The effects of online and blended experience on outcomes in a blended learning environment. The Internet and Higher Education, 44, 100708.

Attard, C., \& Holmes, K. (2020). An exploration of teacher and student perceptions of blended learning in four secondary mathematics classrooms. Mathematics Education Research Journal, 122.

Ayala, J. S. (2009). Blended learning as a new approach to social work education. Journal of Social Work Education, 45(2), 277-288.

Baragash, R. S., \& Al-Samarraie, H. (2018). Blended learning: Investigating the influence of engagement in multiple learning delivery modes on students' performance. Telematics and Informatics, 35(7), 2082-2098.

Basogain, X., Olabe, M. Á., Olabe, J. C., \& Rico, M. J. (2018). Computational Thinking in preuniversity Blended Learning classrooms. Computers in Human Behavior, 80, 412-419.

Bauk, S. I. (2015). Assessing students' perception of e-learning in blended environment: an experimental study. ProcediaSocial and Behavioral Sciences, 191, 323-329.

Berga, K. A., Vadnais, E., Nelson, J., Johnston, S., Buro, K., Hu, R., \& Olaiya, B. (2020). Blended learning versus face-to-face learning in an undergraduate nursing health assessment course:
A quasi-experimental study. Nurse Education Today, 96, 104622.

Brodersen, R. M., \& Melluzzo, D. (2017). Summary of Research on Online and Blended Learning Programs That Offer Differentiated Learning Options. REL 2017-228. Regional Educational Laboratory Central.

Buck, J. L., McInnis, E., \& Randolph, C. (2013). The new frontier of education: The impact of smartphone technology in the classroom. In American Society for Engineering Education(Vol. 1, No. 1, pp. 1-11).

Chen, F., Zhou, S., Ji, G., Sundmacher, K., \& Zhang, C. (2009). Blended learning fitting algorithm for polarization curves of fuel cells. International journal of hydrogen energy, 34(13), 5563-5567.

Cho, W., Jung, Y., \& Im, J. H. (2014). Students' evaluation of learning management systems in the personal computer and smart phone computing environments. International Journal of Mobile Communications, 12(2), 142-159.

Creswell, J. W., \& Creswell, J. D. (2013). Research design: Qualitative, quantitative, and mixed methods approaches. Sage publications.

Deschacht, N., \& Goeman, K. (2015). The effect of blended learning on course persistence and performance of adult learners: A difference-in-differences analysis. Computers \& Education, 87, 8389.

Dwiyogo, W. D. (2018). Developing a blended learning-based method for problem-solving in capability learning. Turkish Online Journal 
DOI: https://doi.org/10.24127/ajpm.v10i2.3447

of Educational TechnologyTOJET, 17(1), 51-61.

Dziuban, C., Graham, C. R., Moskal, P. D., Norberg, A., \& Sicilia, N. (2018). Blended learning: the new normal and emerging technologies. International Journal of Educational Technology in Higher Education, 15(1), 3.

Eliyasni, R., Kenedi, A. K., \& Sayer, I. M. (2019). Blended Learning and Project Based Learning: The Method to Improve Students' Higher Order Thinking Skill (HOTS). Jurnal Iqra': Kajian Ilmu Pendidikan, 4(2), 231-248.

Eliyasni, R., Kenedi, A. K., \& Sayer, I. M. (2019). Blended Learning and Project Based Learning: The Method to Improve Students' Higher Order Thinking Skill (HOTS). Jurnal Iqra': Kajian Ilmu Pendidikan, 4(2), 231-248.

Francis, R., \& Shannon, S. J. (2013). Engaging with blended learning to improve students' learning outcomes. European Journal of Engineering Education, 38(4), 359-369.

Francis, R., \& Shannon, S. J. (2013). Engaging with blended learning to improve students' learning outcomes. European Journal of Engineering Education, 38(4), 359-369.

Gröschl, A., Götz, J., Loderer, A., Bills, P., \& Hausotte, T. (2015). Measures of improvement MUVoT, a Blended Learning course on the topic of Measurement Uncertainty for advanced Vocational Training. Procedia CIRP, 27, 111-116.

Haron, H., Abbas, W. F., \& Abd Rahman, N. A. (2012). The adoption of blended learning among Malaysian academicians. Procedia-Social and Behavioral Sciences, 67, 175-181.

Kashefi, H., Ismail, Z., \& Yusof, Y. M. (2012). Overcoming students obstacles in multivariable calculus through blended learning: A mathematical thinking approach. Procedia-Social and Behavioral Sciences, 56, 579-586.

Kashefi, H., Ismail, Z., \& Yusof, Y. M. (2012). Supporting engineering students' thinking and creative problem solving through blended learning. Procedia-Social and Behavioral Sciences, 56, 117-125.

Kashefi, H., Ismail, Z., Yusof, Y. M., \& Rahman, R. A. (2012). Supporting students mathematical thinking in the learning of two-variable functions through blended learning. Procedia-Social and Behavioral Sciences, 46, 36893695.

Kenedi, A. K., Helsa, Y., Ariani, Y., Zainil, M., \& Hendri, S. (2019). Mathematical Connection of Elementary School Students to Solve Mathematical Problems. Journal on Mathematics Education, 10(1), 69-80.

Kim, Y., \& Shon, J. G. (2011). A study on design of K-12 e-learning system for utilization smartphone. Journal of Internet Computing and Services, 12(4), 135-143.

Latterell, C. M., \& Wilson, J. L. (2016). Math Is Like a Lion Hunting a Sleeping Gazelle: Preservice Elementary Teachers' Metaphors of Mathematics. European Journal of Science and Mathematics Education, 4(3), 283-292.

Lin, Y. W., Tseng, C. L., \& Chiang, P. J. (2016). The effect of blended learning in mathematics course. 
DOI: https://doi.org/10.24127/ajpm.v10i2.3447

$\begin{array}{lrr}\text { EURASIA } & \text { Journal } & \text { of } \\ \text { Mathematics, } & \text { Science } & \text { and } \\ \text { Technology } & \text { Education, } & \text { 13(3), } \\ 741-770 . & & \end{array}$

Lothridge, K., Fox, J., \& Fynan, E. (2013). Blended learning: efficient, timely and cost effective. Australian Journal of Forensic Sciences, 45(4), 407416.

Lynch, R., \& Dembo, M. (2004). The relationship between selfregulation and online learning in a blended learning context. The International Review of Research in Open and Distributed Learning, 5(2).

Marcotullio, P. J. (2001). Asian urban sustainability in the era of globalization. Habitat International, 25(4), 577-598.

Markovits, Z., \& Forgasz, H. (2017). "Mathematics is like a lion": Elementary students' beliefs about mathematics. Educational Studies in Mathematics, 96(1), 49-64.

O'Reilly, R., Ramjan, L. M., Fatayer, M., Stunden, A., \& Gregory, L. R. (2020). First year undergraduate nursing students' perceptions of the effectiveness of blended learning approaches for nursing numeracy. Nurse Education in Practice, 102800.

Ramirez-Arellano, A. (2019). Students learning pathways in higher blended education: An analysis of complex networks perspective. Computers \& Education, 141, 103634.

Rienties, B., Tempelaar, D., Nguyen, Q., \& Littlejohn, A. (2019). Unpacking the intertemporal impact of self-regulation in a blended mathematics environment. Computers in Human Behavior, 100, 345-357.
Rifa'i, A. (2018, September). Students' perceptions of mathematics mobile blended learning using smartphone. In Journal of Physics Conference Series (Vol. 1097, No. 1, p. 012153).

Schlingensiepen, J. (2014). Innovation in distance, e-and blended learning in educational mass production using inverted classroom model (ICM). Procedia-Social and Behavioral Sciences, 141, 393-398.

Stuart, A. (2014). A blended learning approach to safety training: Student experiences of safe work practices and safety culture. Safety science, 62, 409-417.

Sudirwan, J., \& Pelawi, D. (2019, August). Indonesian Higher Education Learning Strategy Facing Industry 4.0: Program for Implementing The SPOCs Learning Model. In 2019 International Conference on Information Management and Technology (ICIMTech) (Vol. 1, pp. 548-553). IEEE.

Taylor, J. A., \& Newton, D. (2013). Beyond blended learning: A case study of institutional change at an Australian regional university. The Internet and Higher Education, 18, 54-60.

Tossell, C. C., Kortum, P., Shepard, C., Rahmati, A., \& Zhong, L. (2015). You can lead a horse to water but you cannot make him learn: Smartphone use in higher education. British Journal of Educational Technology, 46(4), 713-724.

Vo, H. M., Zhu, C., \& Diep, N. A. (2017). The effect of blended learning on student performance at course-level in higher education: A meta-analysis. 
DOI: https://doi.org/10.24127/ajpm.v10i2.3447

Studies in Educational Evaluation, 53, 17-28.

Yaghmour, K. S. (2016). Effectiveness of Blended Teaching Strategy on the Achievement of Third Grade Students in Mathematics. Journal of Education and Practice, 7(5), 65-73.

Yao, C. (2019). An investigation of adult learners' viewpoints to a blended learning environment in promoting sustainable development in China. Journal of Cleaner Production, 220, 134143.

Yen, J. C., \& Lee, C. Y. (2011). Exploring problem solving patterns and their impact on learning achievement in a blended learning environment. Computers \& Education, 56(1), 138-145.

Yigit, T., Koyun, A., Yuksel, A. S., \& Cankaya, I. A. (2014). Evaluation of blended learning approach in computer engineering education. Procedia-Social and Behavioral Sciences, 141, 807-812.

$\mathrm{Yu}$, F., \& Conway, A. R. (2012). Mobile/smartphone use in higher education. Proceedings of the 2012 Southwest Decision Sciences Institute, 831-839.

Yustina, Y., Syafii, W., \& Vebrianto, R. (2020). The Effects of Blended Learning and Project-Based Learning on Pre-Service Biology Teachers' Creative Thinking Skills through Online Learning in the Covid-19 Pandemic. Jurnal Pendidikan IPA Indonesia, 9(3), 408-420.

Waha, B., \& Davis, K. (2014). University students' perspective on blended learning. Journal of Higher Education Policy and Management, 36(2), 172-182. doi:10.1080/1360080x.2014.884 677

Zacharis, N. Z. (2015). A multivariate approach to predicting student outcomes in web-enabled blended learning courses. The Internet and Higher Education, 27, 44-53.

Zainuddin, Z., \& Keumala, C. M. (2018). Blended learning method within Indonesian higher education institutions. Jurnal Pendidikan Humaniora, 6(2), 6977. 